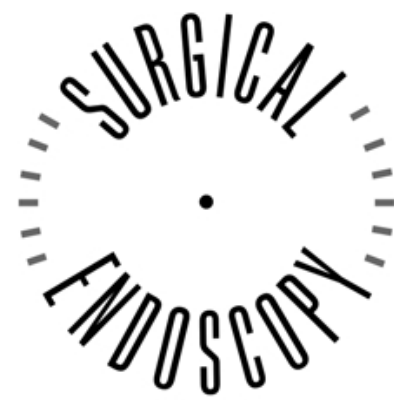

and Other Interventional Techniques

\title{
Intrahepatic lithiasis as a late complication of hepaticojejunostomy
}

C. Lazaridis, B. Papaziogas, A. Alexandrakis, I. Galanis, H. Argiriadou, T. Papaziogas

[Surg Endosc (2003) 17: 661, DOI: 10.1007/s00464-002-4262-x]

The authors would like to add I. Galanis as the fourth contributor to the article. The spelling of the sixth author's surname is "Papaziogas." 